\title{
Mushroom Polysaccharides: a Potent Immune-Modulator
}

\author{
Nilanjan Chakraborty ${ }^{1,2, *(\mathbb{D})}$, Anuron Banerjee ${ }^{2(\mathbb{D})}$, Anik Sarkar ${ }^{1}{ }^{(\mathbb{C})}$, Sandipta Ghosh ${ }^{1}{ }^{\mathbb{C}}$, Krishnendu \\ Acharya 1 (iD \\ 1 Molecular and Applied Mycology and Plant Pathology Laboratory, Department of Botany, University of Calcutta, \\ Kolkata-700019, India \\ 2 Department of Botany, Scottish Church College, Kolkata 700006, India \\ * Correspondence: nilanjanchak85@gmail.com;
}

Scopus Author ID 42761171800

Received: 25.07.2020; Revised: 26.08.2020; Accepted: 27.08.2020; Published: 30.08.2020

\begin{abstract}
From ancient times, mushrooms are being used as nutraceuticals, food supplements, and dietary fibers for their high nutritional value. Modern medicinal researches have depicted immunemodulating effects of wild edible mushrooms. Among several metabolites of mushroom origin, polysaccharides are known to have the most potential immune-modulatory functions on both innate and adaptive immune systems. Mushrooms polysaccharides (MPs) are the diverse groups of macromolecules which show considerable variability in their physicochemical properties. These variations in properties are considered as determining factors of the immune-stimulation activities. In this present review, a broad outline of different MPs and their purification, the relationship between physical properties and bioactivity, immune cell receptors, and impact on both innate and adaptive immune systems is enlightened.
\end{abstract}

Keywords: Cancer adjuvants; dectin-1; immuno-stimulant; polysaccharides receptors.

(C) 2020 by the authors. This article is an open-access article distributed under the terms and conditions of the Creative Commons Attribution (CC BY) license (https://creativecommons.org/licenses/by/4.0/).

\section{Introduction}

With the escalating progression of civilization, mushrooms gained values as immunemodulatory, medicinal and pharmaceutical reinforcement agent, based on the long history of its usage as culinary purposes. Mushrooms are the macrofungi having fleshy spore-bearing fruiting bodies (epigeous or hypogeous) and distinctly conspicuous to the naked eyes $[1,2]$. From ancient times mushrooms and their extracts are being used for improving general health and also for the treatment of other diseases in some Asian countries like China and Japan [3]. China is recognized as the first country to initiate the cultivation of mushrooms all over the world and also secured the first position in mushrooms yielding through the cultivation process. However, the cultivation of mushrooms in India is a new incident, and it was more likely to start in India from the middle of the $19^{\text {th }}$ century. It has been reported earlier that over $1,40,000$ mushrooms species are known to occur worldwide, $10 \%$ of which are known to us among which 2000 species are edible, and approximately 650 species are known for their medicinal and pharmaceutical uses $[4,5]$.

Classic and synthetic drugs are used to treat certain viral pathogens and diseases. Several antibiotics and antiviral drugs are available in the market, but often they are nonfunctional, ineffective in patients due to pathogen resistance, and also cause side effects [6]. During the exploration of potential alternatives, active medicinal compounds obtained from any biological sources are found as non-hazardous and safest. Among them, mushrooms are 
always a great deal of interest in the food and biopharmaceutical industry because of their high nutritional values and for a wide range of bioactive compounds [7]. Dry matter of mushrooms contains approximately $10 \%-40 \%$ of protein, $2 \%-8 \%$ of fat, $3 \%-28 \%$ of carbohydrate, $3 \%-32 \%$ of fiber. Apart from these, a number of bioactive mushroom metabolites like lectins, terpenoid, peptide, glycoproteins play an important role in modulation and boosting up the components of the immune system [8,9]. Several scientific studies and clinical application suggested that mushrooms can act as anti-cancer, anti-inflammatory, anti-microbial, anti-allergic, antidiabetic immune-modulatory agents since they are rich in bioactive metabolites and other phytochemicals [10-12]. Due to such immense medicinal and nutritional benefits, FDA has dignified mushrooms as proper healthy food [13].

Nowadays, mushrooms derived polysaccharides gained a remarkable interest for their immune-modulatory and anti-cancerous properties. In modern medicinal research and pharmaceutical industries, immune-modulators are the main focusing agents [14]. These agents are falls under 2 groups: immune-suppressants (that can able to inhibit and lowers body's immune responses) and immune-stimulants (that can be able to stimulate the immune system by activation of components immune cells like macrophages, natural killer cells, dendritic cells, etc.) [15]. There are several ways by which the human immune system modulates their functions; it may be by endogenous bioactive compounds or by the use of food supplements [16]. Several mushrooms derived polysaccharides have been isolated, which can modulate both innate and adaptive human immune system and can protect from certain autoimmune diseases by interacting with immune cells like NK cells, macrophages, lymphocytes, dendritic cells through cytokine productions [17-22]. For example, polysaccharides like lentinan, polysaccharide peptide (PSP), Schizophyllan, polysaccharide K (Kerstin) are used in cancer immunotherapy $[23,24]$. Most of the mushrooms polysaccharides are glucans, and they show a highly complex structure, where $\beta$-D-glucans are linked with various types of monosaccharide units with the help of glycosidic bonds. Besides this, other different glycosidic linkages may also found to occur, such as $(1 \rightarrow 3),(1 \rightarrow 6)$ - $\beta$-glucans, and $(1 \rightarrow 3)$ - $\alpha$-glucans. The immune-modulatory properties of mushroom polysaccharides are depended on their branching pattern, side-chain modification, high molecular weight, and the ability to interact with different receptors such as dectin-1 [25]. Several scientific investigations have revealed that glucans, mannans, galactans, and fructans, are some other well studied MPs having potential immune-stimulatory activities [26].

A large number of studies have investigated several bioactive polysaccharides from different mushrooms over the years, which have potent antitumor and immune-stimulatory functions. In this present review, we will discuss the details structures of different mushrooms polysaccharides and their bioactivity with immune-modulatory mechanisms.

\section{Bioactive Mushroom's Polysaccharides (MP)-an Overview}

Among all the bioactive compounds, polysaccharides are the most potent, well studied, and widely distributed compounds responsible for the bioactivities of some mushrooms species. Mushroom polysaccharides are a structurally diverse group of a macromolecule with a common $\beta$-linked glucose backbone [27]. Glucans are very common polysaccharides present in the fungal cell wall, mainly in the form of cellulose and reported as one of the potent antitumor polysaccharides [28, 29]. However, for chitin and chitosan (a deacetylated form of chitin), no such activities were reported [30]. Among several polysaccharides, $\beta$-glucans are 
the well studied bioactive component that can enhance the immune system by various strategies such as activation of macrophages [31, 32].

Polysaccharides can be divided into two distinct groups, homopolysaccharides, contains only one kind of monosaccharide unit (homo PSs), and heteropolysaccharides, contains different types of monosaccharide units (hetero PSs), and they may possess different homo or hetero linkage position in accordance to their configuration [33]. Hetero PSs have various types of glycosidic linkages on the basis of their sequence of monosaccharide units, which gives the structural variability of MPs [34]. Lentinan, a $\beta-1,3-D$-glucan with triplehelical conformation, was the first MP isolated from Lentinus edodes (shiitake) in Japan having immune-modulating and anti-cancer activity [35]. Besides this, several other MPs like ganoderan from Ganoderma lucidum, calocyban from Calocybe indica, pleuran from Pleurotus species, were reported as representatives of $\beta$-D-glucans with glycosidic linkages at different position and can be distinguished with different molecular weight and branching pattern [36].

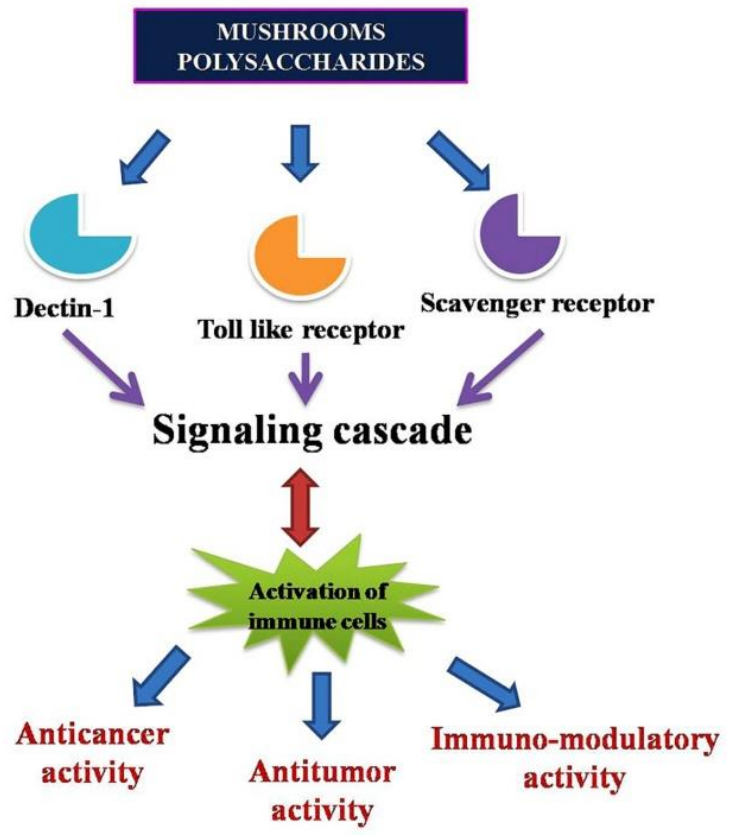

Figure 1. Concept of biological activities of mushrooms polysaccharides.

Earlier reports have suggested that homo PSs, especially $\beta$-D-glucan are the only MPs with bioactive properties, but later studies revealed that heteroPSs are also capable of showing bioactivity. HeteroPSs are more complex than $\beta$-D-glucose since they possess more variability in their monosaccharide composition, linkage, and branching patterns, and some of these molecules show natural methylation $[37,38]$. Glucose, galactose, fructose, fucose, arabinose, xylose, mannitol, trehalose are some very common monosaccharides components detected from MPs [39]. Mushroom polysaccharides extracted from Agaricus bisporus have a direct action against breast cancer. Along with this recently, researchers have found a proteoglycan from A. blaze $i$ having tremendous immune-modulatory activities and can act as therapeutic agents against certain immune-deficient diseases by the regulation of dendritic cells [40].

The overall concept about the immune-modulatory, antitumor and anti-cancer activities (Figure 1) of these MPs are due to their diverse structural conformation, variability in monosaccharide composition and ability to interact with several polysaccharide receptors present on the cell surface (dectin-1, toll-like receptors) which ultimately activate different immune cells like cytotoxic macrophages, natural killer cells, dendritic cells, cytokines [41]. 
However, more studies are needed in the future to understand the relationship between structural conformation and the corresponding immune function mechanism of these MPs.

\section{Production/Purification of Mushrooms Polysaccharides}

Several medicinally important food supplements and nutraceuticals obtained from MPs are now available in the market, but it was still unknown about the fact that how to extract these polysaccharides from fruiting bodies or other parts of the mushrooms. Mizuno et al. were able to give a reliable approach to the extraction and purification of MPs from fruiting bodies in Japan $[42,43]$. The overall procedure is an ethanol (80\%) extraction, which eliminates low molecular weight polysaccharides followed by three successive water extractions in addition to ammonium oxalate and $\mathrm{NaOH}$. Polysaccharides extracted from this procedure are further purified by using a few combinations of techniques such as acidic precipitation, ethanol concentration, fractional precipitation with gel filtration, ion-exchange chromatography, and affinity chromatography. Neutral polysaccharides can be separated from acidic ones by the help of ion-exchange chromatography through DEAE cellulose columns, $\alpha$ and $\beta$-glucans are then purified from high molecular weight neutral polysaccharides through gel filtration chromatography [43, 44]. The general extraction procedure of the mushrooms polysaccharides presented schematically in Figure 2.

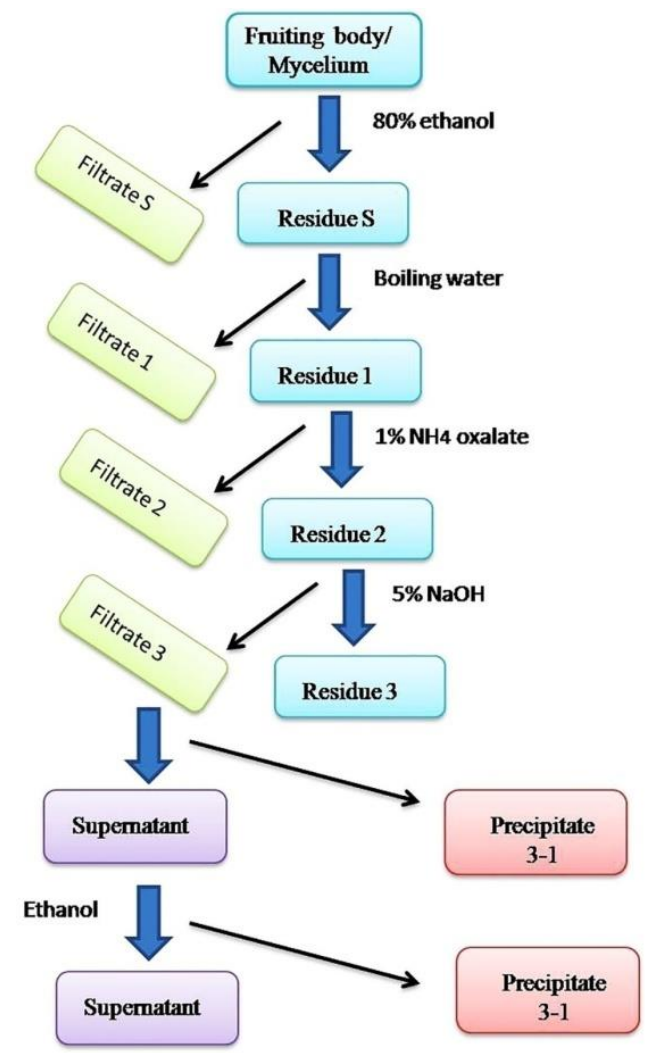

Figure 2. Schematic representation showing purification of polysaccharides from mushrooms.

The production of pleuran, a polysaccharide from Pleurotus ostreatus can be made by using submerged and solid-state fermentation. Extracellularly produced polysaccharides of $P$. ostreatus can be extracted by direct precipitation method followed by using cold ethanol and lyophilization. The endopolysaccharides are extracted using the general method of extraction by using hot water, ethanol, and ultracentrifugation [15]. A large number of scientific 
investigations have revealed several potential bioactive MPs, their source, and immunemodulatory mechanisms, which are outlined in Table 1.

Table 1. Different mushroom polysaccharides, their source, and probable mechanism as immune-modulator.

\begin{tabular}{|c|c|c|c|c|c|}
\hline Scientific name & $\begin{array}{l}\text { Common } \\
\text { name }\end{array}$ & $\begin{array}{l}\text { Bioactive } \\
\text { polysaccharides }\end{array}$ & Parts used & $\begin{array}{l}\text { Immune-modulatory } \\
\text { Mechanism }\end{array}$ & Reference \\
\hline Lentinus edodes & Shiitake & Lentinan & Fruiting body & $\begin{array}{l}\text { By enhancing cytokine } \\
\text { production }\end{array}$ & {$[37,45]$} \\
\hline $\begin{array}{l}\text { Ganoderma } \\
\text { lucidum }\end{array}$ & Reishi & Ganoderan & $\begin{array}{l}\text { Fruiting body, } \\
\text { culture broth }\end{array}$ & $\begin{array}{l}\text { By regulating NF-ьB } \\
\text { signaling pathway }\end{array}$ & {$[46,47]$} \\
\hline $\begin{array}{l}\text { Pleurotus } \\
\text { ostreatus }\end{array}$ & $\begin{array}{l}\text { Oyster } \\
\text { mushroom }\end{array}$ & Pleuran & $\begin{array}{l}\text { Fruiting body, } \\
\text { culture broth }\end{array}$ & $\begin{array}{l}\text { Induce gene expression } \\
\text { of cytokines }\end{array}$ & {$[48,49]$} \\
\hline Grifola frondosa & Maitake & Grifolan & $\begin{array}{l}\text { Fruiting body, } \\
\text { culture broth }\end{array}$ & $\begin{array}{l}\text { Through macrophage } \\
\text { activation }\end{array}$ & {$[50,51]$} \\
\hline $\begin{array}{l}\text { Cordyceps } \\
\text { sinensis }\end{array}$ & $\begin{array}{l}\text { Caterpillar } \\
\text { fungus }\end{array}$ & Cordyglucan & $\begin{array}{ll}\begin{array}{l}\text { Fruiting } \\
\text { culture } \\
\text { mycelium }\end{array} & \text { body, } \\
\end{array}$ & $\begin{array}{l}\text { Induce IL-5 production } \\
\text { to suppress IL-4 and } \\
\text { IL-17 }\end{array}$ & {$[52]$} \\
\hline $\begin{array}{l}\text { Morchella } \\
\text { esculenta }\end{array}$ & Sponge morel & Galactomannan & Fruiting body & Activates macrophages & {$[53]$} \\
\hline $\begin{array}{l}\text { Scizophyllum } \\
\text { commune }\end{array}$ & $\begin{array}{l}\text { Split gill } \\
\text { mushroom }\end{array}$ & schizophyllan & $\begin{array}{l}\text { Whole mushroom, } \\
\text { fruiting body }\end{array}$ & $\begin{array}{l}\text { Activate T-cells and } \\
\text { increase the production } \\
\text { of interleukins }\end{array}$ & {$[38,54]$} \\
\hline $\begin{array}{l}\text { Polystictus } \\
\text { versicolor }\end{array}$ & Turkey tail & $\begin{array}{l}\text { Krestin, } \\
\text { polysaccharide } \\
\text { peptide } \\
\text { polysaccharide } \\
(\mathrm{PSK}),\end{array}$ & $\begin{array}{ll}\begin{array}{l}\text { Fruiting } \\
\text { culture } \\
\text { mycelium }\end{array} & \text { body, } \\
\end{array}$ & $\begin{array}{l}\text { Induced genes that code } \\
\text { cytokines production } \\
\text { and stimulates T-cell } \\
\text { activation }\end{array}$ & {$[55,56]$} \\
\hline Agaricus blazei & $\begin{array}{l}\text { Almond } \\
\text { mushroom }\end{array}$ & $\begin{array}{l}\text { Glycoprotein, } \beta-1,3- \\
\text { glucan }\end{array}$ & $\begin{array}{l}\text { Fruiting body, } \\
\text { culture broth }\end{array}$ & $\begin{array}{l}\text { Induction of TNF and } \\
\text { IL- } 8 \text { production }\end{array}$ & {$[57,58]$} \\
\hline Inonotus obliquus & Chaga & $\beta$-D-glucan & $\begin{array}{l}\text { Fruiting body, } \\
\text { mycelium }\end{array}$ & $\begin{array}{l}\text { Induce the expression } \\
\text { of TNF- } \alpha \text { and IL- } 6 \text { in } \\
\text { macrophages }\end{array}$ & {$[59]$} \\
\hline $\begin{array}{l}\text { Hericium } \\
\text { arinaceus }\end{array}$ & $\begin{array}{l}\text { Pom } \\
\text { mushroom, } \\
\text { monkey head } \\
\text { mushroom }\end{array}$ & $\begin{array}{l}\text { Heteroglycan peptide, } \\
\text { heteroglycan }\end{array}$ & $\begin{array}{l}\text { Fruiting body, the } \\
\text { culture broth }\end{array}$ & $\begin{array}{l}\text { Regulate the expression } \\
\text { of TNF- } \alpha \text { and IL-12 } \\
\text { also induce NO } \\
\text { production }\end{array}$ & {$[60]$} \\
\hline Phellinus linteus & $\begin{array}{l}\text { Black hoof } \\
\text { mushroom }\end{array}$ & Glucan & Fruiting body & $\begin{array}{l}\text { Block production of } \\
\text { TNF- } \alpha, \quad \text { IL- } 4 \\
\text { production, activates } \\
\text { murine B cells }\end{array}$ & [61] \\
\hline Xylaria nigripes & $\begin{array}{l}\text { Dead man's } \\
\text { fingers }\end{array}$ & B-glucan & Whole mushroom & $\begin{array}{ll}\text { Inhibits IFN- } \gamma, & \text { NO, } \\
\text { TNF- } \alpha, & \text { IL-6 } \\
\text { production } & \\
\end{array}$ & {$[62]$} \\
\hline $\begin{array}{l}\text { Sarcodon } \\
\text { aspratus }\end{array}$ & $\begin{array}{l}\text { Black tiger } \\
\text { paw }\end{array}$ & Fucogalactan & Fruiting body & $\begin{array}{l}\text { Regulate release } \\
\text { TNF- } \alpha \text { and } \\
\text { macrophages }\end{array}$ & {$[63]$} \\
\hline $\begin{array}{l}\text { Flammulina } \\
\text { velutipes }\end{array}$ & $\begin{array}{l}\text { Golden needle } \\
\text { mushroom }\end{array}$ & $\begin{array}{l}\text { Homogeneous } \\
\text { heteropolysaccharide }\end{array}$ & Fruiting body & $\begin{array}{l}\text { Increases proliferation } \\
\text { of mouse spleen } \\
\text { lymphocytes and } \\
\text { antibody levels such as } \\
\text { IgM and IgG } \\
\end{array}$ & {$[64]$} \\
\hline Pleurotus eryngii & $\begin{array}{l}\text { King trumpet } \\
\text { mushroom }\end{array}$ & $\begin{array}{l}\text { 3-O-methylated } \\
\text { heterogalactan }\end{array}$ & Fruiting body & $\begin{array}{l}\text { Activates murine } \\
\text { macrophage cells via } \\
\text { toll-like receptor-2 } \\
\text { pathway and stimulates } \\
\text { the secretion of } \\
\text { cytokines and other } \\
\text { immune mediators. }\end{array}$ & {$[65]$} \\
\hline
\end{tabular}

\section{Factors Determining Immune-Stimulatory Activities of Mushrooms Polysaccharides}

A detailed study over the past several years on the structure-activity of mushrooms polysaccharides has revealed the correlation between structural variability and bioactivity. MPs are characterized by highly diversified macromolecules. They show diversity and variability in their molecular weight, helical conformation, branching patterns, sugar composition, chemical 
modification, and other physical properties, which significantly affects their immunestimulatory actions [66, 67].

Molecular weight: Mushroom polysaccharides generally with high molecular weight (500-2000 kDa) appear to be more biologically active in comparison to low molecular weight polysaccharides. [43, 68]. For instance, when four fractions of Polysaccharide K (PSK), each having different molecular masses were extracted from turkey tail mushrooms, the high molecular mass fraction showed the greater immune-modulatory effects [69]. A $\beta$-glucan was reported from Grifola frondosa with high molecular mass ( $<800 \mathrm{kDa})$ known to have antitumor and immune-modulatory activity [70]. This study has revealed the fact that for immunestimulatory activities, high molecular weight polysaccharides are the most appropriate macromolecules. However, there are some low molecular weight polysaccharides, which also showed significant bioactivity. For example, certain low molecular weight polysaccharides fractionated from Schizophyllum and Lentinus species exhibited anti-cancer and immunemodulatory potency [71].

Monosaccharides composition: The relationship between the polysaccharides composition and bioactivity has gained attention during the past decade. Polysaccharides composed of monosaccharide residues such as Mannose, Rhamnose, and Fucose are known to have better bioactivity [72]. The Immune response activity of Tremella mesenterica is responsible for Mannose rich exopolysaccharides [73]. Rhamnose rich exopolysaccharides from Lactobacillus rhamnosus shows potential pharmaceuticals activities [74]. Many polysaccharides contain Mannose as their monosaccharides component, which gives protection against some virulent pathogens. Human cells also have Mannose receptors, which can induce cytokines production and confer immune responses [75]. Some of the bioactive MPs and their functional monosaccharide components with immune-stimulatory activities are presented in Table 2.

Table 2.Mushrooms polysaccharides with different active monosaccharides component and their biological

\begin{tabular}{l|l|l|l} 
Mushroom name & $\begin{array}{l}\text { Active } \\
\text { component }\end{array}$ & \multicolumn{1}{c}{ Bctivities. } & Reference \\
\hline Ganoderma lucidum & Rhamnose & $\begin{array}{l}\text { Immune-modulatory, anti- } \\
\text { cancer }\end{array}$ & {$[76]$} \\
\hline Sarcodon aspratus & Mannose, Rhamnose & Immune-modulatory & {$[77]$} \\
\hline Inonotus obliquus & Mannose, Rhamnose, Xylose & Cytokines induction & {$[78]$} \\
\hline Tremella mesenterica & Man & Cytokine stimulation & {$[73,75]$} \\
\hline Agrocybe cylindracea & Glucose, Galactose & Antioxidant activity & {$[79]$}
\end{tabular}

Solubility: The solubility of mushrooms polysaccharides depends on some physical properties like structural configuration, the complexity of side chains, degree of polymerization, and physical organization [80]. When a branched insoluble $(1 \rightarrow 3) \beta$-D-glucan was fractionated from Auricularia auricular-judae, it did not exhibit any bioactivity later it was chemically modified and made water-soluble, and then it was found to be a potential antitumor agent $[81,82]$.

Branching configuration: The degree of branching is another significant attribute of certain MPs to determine the immune-modulatory functions. Most of the immune-modulatory MPs contain linear 1,3 $\beta$-D-glucans configuration in their main chains with a very small number of short branched chains. $\beta$-glucans that possess linear structures with short or no side branches show greater antitumor activities. The degree of branching for Lentinan, Schizophyllan, and polysaccharide K (PSK) is $40 \%(2 / 5), 33 \%(1 / 3)$, and $20 \%(1 / 5)$ 
respectively but they exhibit more or less same bioactivity even though having differences in their degree of branching (DB). The optimal DB for a bioactive MP is between $20 \%$ to $33 \%$ [36, 83]. Debranching of MPs can sometimes increase their bioactivity extensively; for example, pachyman, a branched polysaccharide from Poria cocos showed no or very little bioactivity, but when it made debranched pachymaran, by using hydrolysis and periodate oxidation it exhibited antitumor and great medicinal and pharmaceutical activities [84]. Debranched Lentinan also showed potential antitumor and immune-stimulatory activities [85].

Helical conformation: Most of the bioactive mushroom polysaccharides possess helical structures. Antitumor and immune-modulatory polysaccharides are generally existed as triplehelical conformation, which is considered as the most stable structure of polysaccharides. In a study, when six anti-cancer mushroom polysaccharides, Schizophyllan, Lentinan, Curdlan, Scleroglucan, Cinerean, and $\beta$-D-xylan were taken for treatment of cancer, it was found that all of these MPs adopt triple-helical conformation [86]. A low molecular weight, triple-helical conformation polysaccharide from Hericium erineceus showed great immune-stimulatory effects by inducing NO production and expression of TNF- $\alpha$, it could also activate macrophages [60]. However, single helix conformation also exhibits biological activities; a single helix $\beta$-D-glucan extracted from Auricularia auricular showed potential antitumor activity [87]. MPs with random coil conformation are also capable of showing significant immune-modulatory activity.

Chemical modification: In order to improve the immune-stimulatory and anti-cancer activities, chemical modifications of MPs have been incorporated. This includes hydroxylation, formylmethylation, carboxymethylation, aminoethylation. A sulfated $(1 \rightarrow 3) \beta$-D-glucan isolated from Lentinus edodes showed better immune-modulating, anti-cancer, antitumor activities than its native glucan [88]. Another study showed that the linear $(1 \rightarrow 3) \alpha$-glucans isolated from Amanita muscaria and Agrocybe cylindracea have very little anti-cancer activity than its carboxymethylated form which showed great antitumor activity against sarcoma 180 and also immune-modulatory activity in mice $[89,90]$.

\section{Immune Cell Receptors of Mushrooms Polysaccharides}

When an infection occurs, the innate immune system is the first line of a defense system that draws barriers to the pathogens or other foreign particles and helps to slow down the infection followed by developing acquired immune responses. Phagocytes are activated in the innate immune system when a pathogen enters the host cell and eliminates the pathogens through phagocytosis [91]. Multicellular organisms recognize infectious molecules and foreign particles through pattern recognition receptors. These receptors identify pathogen-related macromolecules or foreign structures through pathogen-associated molecular patterns (PAMPs). Most of the immune-modulatory MPs are the derivatives of $\beta$-glucans, and they are considered as PAMPs [38]. Due to high molecular mass MPs cannot penetrate cells, so they need certain immune cell receptors to bind. Some of the wells studied $\beta$-glucan receptors are dectin-1, scavenger receptors, complement receptor 3, lactosylceramide, and toll-like receptors (TLR-2, TLR-4) [92].

Dectin-1 is the most studied and important fungal polysaccharide receptors. It is a typeII transmembrane receptor belongs to the C-type lectin family receptor, which comprises four component extracellular carbohydrate recognition domain, a stalk, a transmembrane region, and a short intracellular tail [93]. These receptors bind specifically $(1 \rightarrow 3) \beta$-D-glucans with 
branched side chains. Dectin-1 has a variety of biological activities such as the killing of fungal cells, activation of macrophages, dendritic cells and neutrophil responses, phagocytosis, cytokines productions [94]. In a signaling pathway, dectin-1 works with TLR to generate immune responses by the increased production of cytokines such as tumor necrosis factor (TNF- $\alpha$ ) and interleukine-2 [95].

Complement receptor-3 (CR 3) is other mushrooms $\beta$-glucan receptor, which is widely expressed by neutrophil, monocytes, natural killer cells, dendritic cells, and macrophages. CR3 is a dimer comprises two domains CD11b and CD18 [96]. CR 3 has several diverse groups of ligands and complement components, which helps other low-affinity receptors to bind with the cytoskeleton. CD11b is a lectin domain, and it has a high affinity for $\beta$-glucan. In a study, it was found that when neutrophil was added in a $\beta$-glucan solution in the presence of spleen tyrosine kinase, it showed cytotoxicity, which was mediated by CR 3 signaling pathway [97].

Scavenger receptors are expressed by myeloid and endothelial cells. It is a heterogeneous protein molecule comprises of two intracellular domains, one extracellular domain, and two transmembrane domains. It activates certain signaling pathway like mitogenactivated protein kinase (MAPK), endothelial nitric oxide synthase however there is no such reports found about the activity on fungal metabolites, more studies are needed to understand their activity on MPs [98].

Toll-like receptors (TLR) are certain transmembrane receptors expressed widely in the presence of microbes, fungi, and protozoa. TLR-1 binds specifically lipoglycans, TLR-4 binds bacterial lipopolysaccharides, TLR-5 binds flagellin, and as a result, phagocytosis is initiated by activation of several degrading enzymes. Polysaccharides from Phellinus linteus can activate TLR signaling, which helps in the maturation of dendritic cells through MAPK and p38 signaling pathway [99]. In the presence of fungal components, TLR-2 and TLR-4 can induce inflammatory mediators and trigger the expression of cytokines and chemokines. The induce production of pro-inflammatory cytokine in the yeast phagosomes by detecting fungal components was mediated by TLRs. TLR-4 can mediate the macrophage activation in the presence of a $\beta$-glucan polysaccharide isolated from Ganoderma species, which results in activation of NF-вB [100, 101].

\section{Response of Mushrooms Polysaccharides on Immune System}

Mushrooms and their extracts are well known for their medicinal and pharmaceutical values from ancient times. The present scientific researches are now able to understand the reasons and detailed mechanisms behind the enormous biological activities of these mushrooms metabolites. In recent times different mushrooms metabolites are increasingly gaining importance in health industries due to their immune-modulating ability. $\beta$-glucans are detected as the most common MPs which are capable of exhibiting several immune responses, including induction of cytokines production, inhibition of tumor growth, and also shows anticancer activities. The cell surface immune cells receptors recognized these polysaccharides through pattern recognition receptors resulting in activation of macrophages, maintain the balance of the $\mathrm{T}$ helper cell population via cytokine production [102]. The overall hostmediated immune-modulation effects of MPs comprises both innate (macrophages, dendritic cells, natural killer cells, neutrophil) and adaptive (T cell and B cell) immune responses. 


\section{Effects on the Innate Immune System}

Macrophages or monocytes are particularly responsible for the production of TNF- $\alpha$, IL-1, IL-6, IL-10, IL-12 and also helps to maintain the balance between Th1 and Th2. Lentinan, grifolan, Schizophyllan are some of the most potent immune-modulatory MPs which can activate macrophages $[17,103]$. The activated macrophages enhance the production of cytokines such as IL-1 and TNF- $\alpha$, which ultimately leads to immune stimulation. TNF- $\alpha$ can act as both tumor-inhibiting and promoting factors and can also induce the production of some other cytokines that may play an important biological role [104]. After treating a macrophage culture with a polysaccharide isolated from the fresh fruiting body of Ganoderma lucidum, it showed 29 times higher levels of TNF- $\alpha$ and IL-1 than its untreated culture [105]. A polysaccharide fraction from Sarcodon aspratus exhibited immune-modulation responses by releasing TNF- $\alpha$ and NO in the macrophages of mice. This might also help to inhibit tumor formation and other immune-modulatory effects [99].

NK cells are the class of lymphocytes, which shows defense responses against intracellular infections by killing them. It produces cytokine IFN- $\gamma$ which activates macrophages. NK cells exhibit cytotoxic activities to certain pathogens, which involves recognition and lysis of the infected cells. NK cells stimulate the immune responses by the production of IFN- $\gamma$, TNF- $\alpha$, and GN-CSF. Activated dendritic cells can stimulate NK cells to produce cytokines that contribute to innate immune responses [106]. Hot water extracts of Agaricus blazei can induce the activity of NK cells in the spleen cells of mice besides this it can also enhance the production of cytotoxic T lymphocytes and IFN- $\gamma$ [107]. A scientific study has revealed that water extracts of five medicinally important mushrooms such as Lentinus edodes, Coriolus versicolor, Cordyceps sinensis, Agaricus blazei, Ganoderma lucidum enhanced the NK cell activities in mice and also suppressed the growth of B-16 melanoma [108].

Dendritic cells (DCs) are the antigen-presenting cells (APC) and central component of the innate immune system, which can regulate the expression of both native T cells and B cells. They induce tumor immunity by regulating NK cell levels and also by developing cells of the adaptive immune system. Polysaccharide K (PSK) isolated from Coriolus versicolor can induce the maturation of DCs in human CD14 mononuclear cells. Moreover, it can reverse the immune-suppressive state of certain cancer-bearing organisms through the maturation of DCs [109]. It was reported that polysaccharide from Ganoderma lucidum could stimulate the maturation of DCs derived from murine bone marrow and also capable of showing significant immune-modulation responses [110]. Phellinus linteus and Agaricus blazei can produce IL-12 in DCs [17].

\section{Effects on Adaptive Immune System}

T cells or $\mathrm{T}$ lymphocytes are of two types $\mathrm{T}$ helper cells $\left(\mathrm{T}_{\mathrm{H}}\right)$ and cytotoxic $\mathrm{T}$ cells $\left(\mathrm{T}_{\mathrm{C}}\right)$. $\mathrm{T}_{\mathrm{H}}$ cells can interact with B cells and help them to divide and killing intracellular pathogens while TC cells directly destroy infected host cells [111]. The activation of $\mathrm{T}$ cells is mediated by $\mathrm{CD}^{+}$through secretion of a certain number of cytokines, which also induce the production of innate immune cells. $T_{H} 1$ contributes to cellular immunity by producing cytokines such as IFN- $\gamma$, TNF- $\beta$, and IL- 2 while $\mathrm{T}_{\mathrm{H}} 2$ contributes to humoral immunity by producing IL-4, 5, 6 , 10, and 13 [99]. D-fraction from Grifola frondosa controls the balance of $\mathrm{T}_{\mathrm{H}} 1$ and $\mathrm{T}_{\mathrm{H}} 2$ and can inhibit the activation of B cells resulting in enhances cellular immunity [112]. Lentinan has 
considered a T cell oriented adjuvants [113]. A glucan from Sclerotinia sclerotiorum can induce the response of $\mathrm{T}_{\mathrm{H}}$ cells via the IL-12 pathway [114]. Besides MPs several fungal immune-modulatory proteins (FIP) can also induce T cell-mediated bioactivities. For example, FIP from two edible mushrooms Volvariella volvacea can induce the expression of both $\mathrm{T}_{\mathrm{H}} 1$ and $\mathrm{T}_{\mathrm{H}} 2$ specific cytokine [115].

There are many mushrooms metabolites which can activate B cells mediated immunestimulation. A proteoglycan from Phellinus linteus was found to involves in this process. Three polysaccharides extracted from the fruiting body of Ganoderma lucidum (PL-1, PL-3, and PL4) enhanced proliferation of B cells, PL-1 have immune-stimulatory functions [116]. A proteoglycan from Ganoderma lucidum was found to stimulate the activation marker of murine splenic B cells, which induced their differentiation into IgM secreting plasma cells[117, 118]. However, there are some MPs that suppress B cells' function. For instance, a polysaccharide obtained from Ganoderma spores inhibits the function of antibody-producing cells in mice [116]. Recently, a purified polysaccharide isolated from Poria cocos was tested for its adjuvant property on inactivated rabies vaccine. It was found that the polysaccharide was capable of activating both humoral and cellular immune responses in mice as well as dogs, and also it markedly induced cytokines secretion from splenocytes [119].

\section{Conclusions}

The immune-modulatory effects of different mushrooms polysaccharides are presented in this review. One of the main goals of the present and advance medical researches is to discover new and safe drugs with no or very negligible side effects. In the past 20 years, research on MPs has increased significantly; the most studied biological activities of these MPs are immune-modulation, anti-cancer, and tumor inhibition. Clinical studies have suggested that nutraceuticals obtained from medicinal mushrooms are considered as natural drugs with very few side effects. Mushrooms polysaccharides are the emerging new agents that could enhance immune responses. The effectiveness of a drug obtained from any natural resources solely depends on the dose, concentration, methods of purification, and duration of treatment. The medicinal properties of different mushrooms species have been determined, and it was found that there are remarkable differences in their immune-modulating properties. We have represented a different source of immune-modulatory polysaccharides from different mushrooms with their corresponding effects on the immune system. The major immunestimulatory effects of these MPs include activation of different immune cells. Different physical properties of polysaccharides can play an important role in their bioactivity. The biochemical mechanisms of polysaccharides are still unclear; more studies are needed on different mushrooms species and their extracts to understand the detailed mechanisms of how they inhibit tumor formation and can act as adjuvants in cancer therapy. More clinical trials should be done on humans to understand the bioactivities of different polysaccharide fractions. Different investigations are still going on to improve the immune-stimulatory activities of MPs, which will also increase their clinical qualities.

\section{Funding}

This research received no external funding. 


\section{Acknowledgments}

This research has no acknowledgment.

\section{Conflicts of Interest}

The authors declare no conflict of interest.

\section{References}

1. Chang, S.T.; Miles, P.G. Mushroom biology-a new discipline. Mycologist 1992, 6, 64-65, https://doi.org/10.1016/S0269-915X(09)80449-7.

2. Cheung, P.C.K. Mini-review on edible mushrooms as source of dietary fiber: Preparation and health benefits. FSHW 2013, 2, 162-166, https://doi.org/10.1016/j.fshw.2013.08.001.

3. Guggenheim, A.G.; Wright K.M.; Zwickey,H.L.Immune Modulation From Five Major Mushrooms: Application to Integrative Oncology. Integr Med (Encinitas) 2014, 13, 32-44.

4. Wasser, S.P. Medicinal mushrooms as a source of antitumor and immune-modulating polysaccharides. Appl Microbiol Biotechnol 2002, 60, 258-274, https://doi.org/10.1007/s00253-002-1076-7.

5. Adhikari, M.; Bhusal, S.; Pandey, M.R.; Raut, J.K.; Bhatt, L.R. Mycochemical and Nutritional Analysis of Selected Wild Mushrooms from Gaurishankar Conservation Area, Nepal. Int J Pharmacogn Chinese Med 2019, 3, 1-7.

6. Brijesh, S.; Daswani, P.; Tetali, P.; Antia, N.; Birdi, T. Studies on the antidiarrhoeal activity of Aegle marmelos unripe fruit: validating its traditional usage. BMC Complement Altern Med 2009, 9, 1-12, https://doi.org/10.1186/1472-6882-9-47.

7. Taofiq, O.; Paramas, A.M.G.; Martins, A.; Barreiro, M.F.; Farreira, I.C.F.R. Mushrooms extracts and compounds in cosmetics, cosmeceuticals and nutricosmetics-A review. Ind Crops Prod 2016, 90, 3848,https://doi.org/10.1016/j.indcrop.2016.06.012.

8. Breene, W.M. Nutritional and medicinal value of speciality mushrooms. J Food Prot 1990, 53, 883-894, https://doi.org/10.4315/0362-028X-53.10.883.

9. Rathore, H.; Prasad, S.; Sharma, S. Mushroom nutraceuticals for improved nutrition and better human health: A review. Pharma Nutrition 2017, 5, 35-46, https://dx.doi.org/10.1016/j.phanu.2017.02.001.

10. Moradali, M.F.; Mostafavi, H.; Ghods, S.; Hedjaroude, G.A. Immunomodulating and anti-cancer agents in the realm of macromycetes fungi (macrofungi). Int. Immunopharmacol 2007, 7, 701-724, https://doi.org/10.1016/j.intimp.2007.01.008.

11. Lu, M.K.; Cheng, J.J.; Lin, C.Y.; Chang, C.C. Purification, structural elucidation and anti-inflammatory effect of a water soluble 1,6-branched 1,3- $\alpha$-d-galactan from cultured mycelia of Poria cocos. Food Chem 2010, 118, 349-356, https://doi.org/10.1016/j.foodchem.2009.04.126.

12. Jiang, X.; Meng, W.; Li, L.; Meng, Z.; Wang, D. Adjuvant Therapy With Mushroom Polysaccharides for Diabetic Complications. Front. Pharmacol 2020, 11, 1-12, https://doi.org/10.3389/fphar.2020.00168.

13. Sinha, S.K.; Upadhyay T.K.; Sharma S.K. Nutritional-medicinal profile and quality categorization of fresh white button mushroom. Biointerface Res Appl Chem 2021, 11, 8669-8685, 10.33263/BRIAC112.86698685

14. Kothari, D.; Patel, S.; Kim, S.-K. Anticancer and other therapeutic relevance of mushroom polysaccharides: A holistic appraisal. Biomed Pharmacother 2018, 105, 377-394, https://doi.org/10.1016/j.biopha.2018.05.138.

15. Enshasy, H.A.E.; Kaul, R.H. Mushroom immunomodulators: unique molecules with unlimited applications. Trends Biotechnol2013, 31, 668-77, https://doi.org/10.1016/j.tibtech.2013.09.003.

16. Wu, D.; Lewis, E.D.; Pae, M.; Meydani, S.N.Nutritional Modulation of Immune Function: Analysis of Evidence, Mechanisms, and Clinical Relevance. Front Immunol 2018, 9, 1-19, https://dx.doi.org/10.3389\%2Ffimmu.2018.03160.

17. Borchers, A.T.; Keen, C.L.; Gershwin, M.E. Mushrooms, tumors, and immunity: an update. Exp Biol Med (Maywood) 2004, 229, 393-406, https://doi.org/10.1177/153537020422900507.

18. Cornò, M.D.; Gessani, S.; Conti, L. Shaping the Innate Immune Response by Dietary Glucans: Any Role in the Control of Cancer? Cancers (Basel) 2020, 12, 1-17, https://dx.doi.org/10.3390\%2Fcancers12010155.

19. Cheng, X.-D.; Wu, Q.-X.; Zhao, J.; Su, T.; Lu, Y.-M.; Zhang, W.-N., ... Chen, Y. Immunomodulatory effect of a polysaccharide fraction on RAW 264.7 macrophages extracted from the wild Lactarius deliciosus. Int $J$ Biol Macromol 2019, 128, 732-739. https://doi.org/10.1016/j.ijbiomac.2019.01.201

20. Chen, S.; Liu, C.; Huang, X.; Hu, L.; Huang, Y.; Chen, H.; ... Nie, S. Comparison of immunomodulatory effects of three polysaccharide fractions from Lentinula edodes water extracts. J Func. Foods 2020, 66, 103791,https://doi.org/10.1016/j.jff.2020.103791

21. Meng, X.; Che, C.; Zhang, J.; Gong, Z.; Si, M.; Yang, G.; ... Liu, J. Structural characterization and immunomodulating activities of polysaccharides from a newly collected wild Morchella sextelata. Int JBiol Macromol 2019,15, 608-614.https://doi.org/10.1016/j.ijbiomac.2019.01.226 
22. Liu, Y.; Zhou, Y.; Liu, M.; Wang, Q.; Li, Y.Extraction optimization, characterization, antioxidant and immunomodulatory activities of a novel polysaccharide from the wild mushroom Paxillus involutus. Int JBiol Macromol 2018, 112, 326-332. https://doi.org/10.1016/j.ijbiomac.2018.01.132

23. Lindequist, U.; Niedermeyer, T.H.J.; Jülich, W.D. The pharmacological potential of mushrooms. Evid Based Complement Altern Med 2005, 2, 285-299, https://dx.doi.org/10.1093\%2Fecam\%2Fneh107.

24. Reis, F.S.; Martins, A.; Vasconcelos, M.H.; Morales, P.; Ferreira, I.C.F.R. Functional foods based on extracts or compounds derived from mushrooms. Trends Food Sci Tech 2017, 66, 48-62, https://doi.org/10.1016/j.tifs.2017.05.010.

25. Mingyi, Y.; Belwal, T.; Devkota, H.P.; Li, L.; Luo, Z. Trends of utilizing mushroom polysaccharides (MPs) as potent nutraceutical components in food and medicine: A comprehensive review. Trends Food Sci Technol 2019, 92, 94-110, https://doi.org/10.1016/j.tifs.2019.08.009.

26. Ferreira, S.S.; Passos, C.P.; Madureira, P.; Vilanova, M.; Coimbra, M.A. Structure function relationships of immunostimulatory polysaccharides: A review. Carbohydr polym 2015, 132, 378-396, https://doi.org/10.1016/j.carbpol.2015.05.079.

27. Nakashima, A.; Yamada, K.; Iwata, O.; Sugimoto, R.; Atsuji, K.; Ogawa, T.; Ishibashi-Ohgo, N.; Suzuki, K. $\beta$-Glucan in Foods and Its Physiological Functions. J. Nutr. Sci. Vitaminol 2018, 64, 8-17, https://doi.org/10.3177/jnsv.64.8.

28. Chaitanya, M.; Jose, A.; Ramalingam, P.; Mandal, S.C.; Kumar, P.N. Multi-targeting cytotoxic drug leads from mushrooms. Asian Pac J Trop Med 2019, 12, 531-6, https://doi.org/10.4103/1995-7645.272482

29. Pandya, U.; Dhuldhaj, U.;Sahay, N.S. Bioactive mushroom polysaccharides as antitumor: an overview. Nat Prod Res 2018, 1-13. https://doi.org/10.1080/14786419.2018.1466129

30. Mizuno, T.; Saito, H.; Nishitoba, T.; Kawagashi, H. Antitumor active substances from mushrooms. Food Rev Int 1995, 11, 23-61, https://doi.org/10.1080/87559129509541018.

31. Batbayar, S.; Lee, D.H.; Kim, H.W. Immunomodulation of Fungal $\beta$-glucan in host defines signaling by dectin-1. Biomol Ther 2012, 20, 433-445, https://doi.org/10.4062/biomolther.2012.20.5.433.

32. Yang, Y.; Zhao, X.; Li, J.; Jiang, H.; Shan, X.; Wang, Y.; Ma, W.; Hao, J.; Yu, G. A $\beta$-glucan from Durvillaea Antarctica has immunomodulatory effects on RAW264.7 macrophages via toll-like receptor 4. Carbohydr. Polym 2018, 191, 255-265, https://doi.org/10.1016/j.carbpol.2018.03.019.

33. Pandya, U.; Dhuldhaj, U.; Sahay N.S. Bioactive mushroom polysaccharides as antitumor: an overview. Nat Prod Res 2019, 33, 2668-2680, https://doi.org/10.1080/14786419.2018.1466129.

34. Ruthes, A.C.; Smiderle, F.R.; Iacomini, M. Mushroom heteropolysaccharides: A review on their sources, structure and biological effects. Carbohydr Polym 2016, 136, 358-375, https://doi.org/10.1016/j.carbpol.2015.08.061.

35. Ikekawa, T.; Uehara, N.; Maeda, Y.; Nakanishi, M.; Fokuoka, F. Antitumor activity of aqueous extracts of edible mushrooms. Cancer Res 1969, 29, 734-735.

36. Villares, A.; Vivaracho, L.M.; Guillamón, E. Structural features and healthy properties of polysaccharides occurring in mushrooms. Agricult 2012, 2, 452-471, https://doi.org/10.3390/agriculture2040452.

37. Carbonero, E.R.; Gracher, H.P.; Komura, D.L.; Marcon, R.; Freitas, C.S.; Baggio, C.H.; Santos, A.R.S.; Torri, G.; Gorin, P.A.G.; Iacomini, M. Lentinus edodes heterogalactan: Antinociceptive andantiinflammatory effects. Food Chem 2008, 111, 531-537, https://doi.org/10.1016/j.foodchem.2008.04.015.

38. Ayeka, P.A. Potential of Mushroom Compounds as Immunomodulators in Cancer Immunotherapy: A Review. Evid Based Complement Alt Med 2018, 2018, 1-10.

39. Valverde, M.E.; Hernández-Pérez, T.; Paredes-López, O. Edible mushrooms:improving human health and promoting quality life. Int J Microbiol 2015, 7, 1-14.

40. Kim, Y.W.; Kim, K.H.; Choi, H.J.; Lee, D.S. Anti-diabetic activity of beta-glucans and their enzymatically hydrolyzed oligosaccharides from Agaricus blazei. Biotechnol Let 2005, 27, 483-487, https://doi.org/10.1007/s10529-005-2225-8.

41. Wasser, S.P. Current findings, future trends, and unsolved problems in studies of medicinal mushrooms. Appl Microbiol Biotechnol 2011, 89, 1323-1332, https://doi.org/10.1007/s00253-010-3067-4.

42. Mizuno, T. Development of antitumor polysaccharides from mushroom fungi. Foods Food Ingred J Jpn 1996, 167, 69-85.

43. Mizuno, T. The extraction and development of antitumor-active polysaccharides from medicinal mushrooms in Japan. Int J Med Mushrooms 1999, 1, 9-29, http://dx.doi.org/10.1615/IntJMedMushrooms.v1.i1.20.

44. Baeva, E.; Bleha, R.; Lavrova, E.; Sushytskyi, L.; Copiková, J.; Jablonsky, I.; Kloǔcek, P.; Synytsya, A. Polysaccharides from Basidiocarps of Cultivating Mushroom Pleurotus ostreatus: Isolation and Structural Characterization. Molecules 2019, 24, 1-16, https://doi.org/10.3390/molecules24152740.

45. Bisen, P.S.; Baghel, R.K.; Sanodiya, B.S.; Thakur, G.S.; Prasad, G.B.K.S. Lentinus edodes: a macrofungus with pharmacological activities. Cur Med Chem 2010, 17, 2419-2430, https://doi.org/10.2174/092986710791698495.

46. Pan, D.; Wang, L.; Chen, C.; Teng, B.; Wang, C.; Xu, Z.; Hu, B.; Zhou, P. Structure characterization of a novel neutral polysaccharide isolated from Ganoderma lucidum fruiting bodies. Food Chem 2012, 135, 1097-1103, https://doi.org/10.1016/j.foodchem.2012.05.071. 
47. Zhu, X.-L.; Chen, A.-F.; Lin, Z.-B. Ganoderma lucidum polysaccharides enhance the function of immunological effector cells in immunosuppressed mice. J Ethnopharmacol 2007, 111, 219-22, https://doi.org/10.1016/j.jep.2006.11.013.

48. Solomko, E.F. The physiology-biochemical properties and biosynthetic activities of higher Basidiomycetes mushroom Pleurotus ostreatus (Jacq.: Fr.) Kumm. In: Submerged culture. Dr. Sci. Thesis, N.G. Kholodny Institute Of Botany Academy of Science, Ukraine-Kiev (Russ.) 1992; pp. 49-63.

49. Siwulska, I.G.; Kałużewicz, A.; Spiżewski, T.; Siwulski, M.; Sobieralski, K.; Bioactive compounds and medicinal properties of Oyster mushrooms (Pleurotus sp). Folia Hort 2018, 30, 191-201, https://doi.org/10.2478/fhort-2018-0012.

50. Mizuno, T.; Zhuang, C. Grifola frondosa: pharmacological effects. Food Rev Int 1995, 11, 135-149, https://doi.org/10.1080/87559129509541024.

51. Seo, Y.-R.; Patel, D.K.; Shin, W.-C.; Sim, W.-S.; Lee, O.-H.; Lim, K.-T. Structural Elucidation and ImmuneEnhancing Effects of Novel Polysaccharide from Grifola frondosa. Bio Med Res Int 2019, 2019, 17, https://doi.org/10.1155/2019/7528609.

52. Chen, P.X.; Wang, S.; Nae, S.; Marcone, M. Properties of Cordyceps sinensis: a review. J Funct Foods 2013, 5, 550-569, https://dx.doi.org/10.1016\%2Fj.jff.2013.01.034.

53. Cui, H.-L.; Chen, Y.; Wang, S.-S.; Kai, G.-Q.; Fang, Y-M. Isolation, partial characterization and immunomodulatory activities of polysaccharide from Morchella esculenta. J Sci Food Agr 2011, 91, 21802185, https://doi.org/10.1002/jsfa.4436.

54. Hobbs, C. The chemistry, nutritional value, immunopharmacology, and safety of the traditional food of medicinal spilit-gill fungus Schizophyllum commune Fr.:Fr. (Schizophyllaceae). A literature review. Int. J. Med. Mushrooms 2005, 7, 127-140, https://doi.org/10.1615/IntJMedMushr.v7.i12.130.

55. Cui, J.; Chisti, Y. Polysaccharopeptides of Coriolus versicolor: physiological activity, uses and production. Biotechnol. Adv 2003, 21, 109-122, https://doi.org/10.1016/s0734-9750(03)00002-8.

56. Saleh, M.H.; Rashedi, I.; Keating, A. Immunomodulatory Properties of Coriolus versicolor: The Role of Polysaccharopeptide. Front immunol 2017, 8, 1-12, https://doi.org/10.3389/fimmu.2017.01087.

57. Mizuno, T. Bioactive substances in Yamabushitake, the Hericium erinaceum fungus, and its medicinal utilization. Food Ingred Jap J 1998, 167, 69-81.

58. Firenzuoli, F.; Gori, L.; Lombardo, G. The medicinal mushroom Agaricus blazei Murrill: review of literature and pharmaco-toxicological problems. Evid Based Complement Altern Med 2008, 5, 3-15.

59. Won, D.P.; Lee, J.S.; Kwon, D.S.; Lee, K.E.; Shin, W.C.; Hong, E.K. Immunostimulating activity by polysaccharides isolated from fruiting body of Inonotus obliquus. Mol Cells 2011, 31, 165-173, https://dx.doi.org/10.1007\%2Fs10059-011-0022-x.

60. Lee, J.S.; Cho, J.Y.; Hong, E.K. Study on macrophage activation and structural characteristics of purified polysaccharides from the liquid culture broth of Hericium erinaceus. Carbohydr. Polym 2009, 78, 162-168.

61. Wu, S.-J.; Liaw, C.-C.; Pan, S.-Z.; Yang, H.-C.; Ng, L.-T. Phellinus linteus polysaccharides and their immunomodulatory properties in human monocytic cells. $J$ Funct Food 2013, 5, 679-688, https://doi.org/10.1016/j.jff.2013.01.011.

62. Ko, H-J.; Song, A.; Lai, M.N.; Ng, L.T. Immunomodulatory properties of Xylaria nigripes in peritoneal macrophage cells of Balb/c mice. $J$ Ethnopharmacol 2011, 138, 762-768, https://doi.org/10.1016/j.jep.2011.10.022.

63. Han, X.-Q.; Wu, X.-M.; Chai, X.-Y.; Chen, D.; Dai, H.; Dong, H.-L.; Ma, Z.-Z.; Gao, X.-M.; Tu, P.-F. Isolation, characterization and immunological activity of a polysaccharide from the fruit bodies of an edible mushroom, Sarcodon aspratus (Berk.) S. Ito. Food Res Int 2011, 44, 489-493, https://doi.org/10.1016/j.foodres.2010.06.009.

64. Wang, W.; Zhang, J.; Feng, T. et al. Structural elucidation of a polysaccharide from Flammulina velutipes and its immunomodulation activities on mouse B lymphocytes. Sci Rep 2018, 8, 3120, https://doi.org/10.1038/s41598-018-21375-0

65. Yan, J.; Meng, Y.; Zhang, M.; Zhou, X.; Cheng, H.; Sun, L.;Zhou, Y. A 3-O-methylated heterogalactan from Pleurotus eryngii activates macrophages. Carbohydr Polym 2018, 206, 706-715 https://doi.org/10.1016/j.carbpol.2018.11.063

66. Zhang, L.; Li, C.G.; Liang, H.; Reddy, N. Bioactive Mushroom Polysaccharides: Immunoceuticals to Anticancer Agents. J Nut Food Sci 2017, 2, 1-6.

67. Ghosh,S.; Khatua, S.; Acharya,K. Crude polysaccharide from a wild mushroom enhances immune response

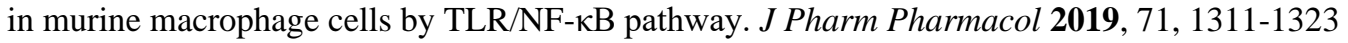

68. Chaturvedi, V.K.; Agarwal, S.; Gupta, K.K.; Ramteke, P.W.; Singh, M.P. Medicinal mushroom: Boon for therapeutic applications. 3 Biotech 2018, 8, 334, https://doi.org/10.1007/s13205-018-1358-0

69. Sakagami, H.; Kim, F.; Konno, K. Stimulation of human peripheral blood polymorphonuclear cell iodination by PSK subfractions. Anticancer Res 1990, 10, 697-702.

70. Adachi, Y.; Ohno, N.; Ohsawa, M.; Oikawa, S.; Yadomae, T. Change of biological activities of $(1 \rightarrow 3)$ beta D-glucan from Grifola frondosa upon molecular weight reduction by heat treatment. Chem Pha l Bull 1990, 38, 477-481, https://doi.org/10.1248/cpb.38.477. 
71. Ooi, V.E.; Liu, F.Immunomodulation and Anti-Cancer Activity of Polysaccharide- Protein Complexes. Cur Med Chem 2000, 7, 715-729, https://doi.org/10.2174/0929867003374705.

72. Deveci, E.; Çayan, F.; Çayan, G.T.; Duru, M.E. Structural characterization and determination of biological activities for different polysaccharides extracted from tree mushroom species. J Food Biochem 2019, 43, 113, https://doi.org/10.1111/jfbc. 12965.

73. Chen, N.Y.; Hsu, T.H.; Lin, F.Y.; Lai, H.H.; Wu, J.Y. Effects on cytokine-stimulating activities of eps from Tremella mesenterica with various carbon sources. Food Chem 2006, 99, 92-97, https://doi.org/10.1016/j.foodchem.2005.07.023.

74. Chabot, S.; Yu, H.L.; Léséleuc, L.D., Cloutier, D.; Calsteren M.R.V.; Lessard, M.; Roy, D.; Lacroix, M.; Oth, D. Exopolysaccharides from Lactobacillus rhamnosus RW-9595M stimulate TNF, IL-6 and IL-12 in human and mouse cultured immune-competent cells, and IFN- in mouse splenocytes. Dairy Sci Technol 2001, 81, 683-697, https://doi.org/10.1051/lait:2001157.

75. Wang, Q.; Wang, F.; Xu, Z.; Ding, Z. Bioactive Mushroom Polysaccharides: A Review on Monosaccharide Composition, Biosynthesis and Regulation. Molecules 2017, 22, 1-13, https://dx.doi.org/10.3390\%2Fmolecules22060955.

76. Zhang, J.J.; Meng, G.Y.; Zhai, G.Y.; Yang, Y.H.; Zhao, H.; Jia, L. Extraction, characterization and antioxidant activity of polysaccharides of spent mushroom compost of Ganoderma lucidum. Int J Biol Macromol 2015, 82, 432-439, https://doi.org/10.1016/j.ijbiomac.2015.10.016.

77. Im, S.-A.; Wang, W.; Lee, C.-K.; Lee, Y.N. Activation of macrophages by exopolysaccharide produced by MK1 bacterial strain isolated from Neungee mushroom, Sarcodon aspratus. Immune Netw 2010, 10, 230238, https://doi.org/10.4110/in.2010.10.6.230.

78. Xu, X.; Hu, Y.; Quan, L. Production of bioactive polysaccharides by Inonotus obliquus under submerged fermentation supplemented with lignocellulosic biomass and their antioxidant activity. Bioprocess Biosyst Eng 2014, 37, 2483-2492, https://doi.org/10.1007/s00449-014-1226-1.

79. Liu, M.; Jing, H.J.; Zhang, J.J.; Che, G.; Zhou, M.; Gao, Z.; Li, S.; Ren, Z.; Hao, L.; Liu, Y.; Jia, L. Optimization of mycelia selenium polysaccharide extraction from Agrocybe cylindracea SL-02 and assessment of their antioxidant and anti-ageing activities. PLoS One 2016, 11, 1-15, https://doi.org/10.1371/journal.pone.0160799.

80. Zekovic, D.B.; Kwiatkowski, S.; Vrvic, M.M.; Jakovljevic, D.; Moran, C.A. Natural and modified (1 $\rightarrow 3)-$ beta-D-glucans in health promotion and disease alleviation. Crit Rev Biotechnol 2005, 25, 205-230, https://doi.org/10.1080/07388550500376166.

81. Misaki, A.; Kakuta, M.; Sasaki, T.; Tanaka, M.; Miyaji, H. Studies on Interrelation of Structure and Antitumor Effects of Polysaccharides: Antitumor Action of Periodate-Modified, Branched (1 $\rightarrow 3)$-beta-Dglucan of Auricularia auricula-Judae, and Other Polysaccharides Containing (1 Goes to 3)-glycosidic Linkages. Carbohydr Res 1981, 92, 115-129, https://doi.org/10.1016/s0008-6215(00)85986-8.

82. Bandara, A.R.; Rapior, S.; Mortimer, P.E.; Kakumyan, P.; Hyde, K.D.; Xu, J. A review of the polysaccharide, protein and selected nutrient content of Auricularia, and their potential pharmacological value. Mycosphere 2019, 10, 579-607, https://doi.org/10.5943/mycosphere/10/1/10.

83. Miyazaki, T.; Oikawa, N.; Yadomae, T.; Yamada, H.; Yamada, Y.; Hsu, H-Y.; Ito, H. Relationship between the chemical structure and anti-tumour activity of glucans prepared from Grifora umbellata.Carbohydr Res 1979, 69, 165-170, https://doi.org/10.1016/S0008-6215(00)85761-4.

84. Chihara, G.; Hamuro, J.; Maeda, Y.; Arai, Y.; Fukuoka, F. Antitumor polysaccharide derived chemically from natural glucan (pachyman). Nature 1970, 225, 943-944, https://doi.org/10.1038/225943a0.

85. Ren, L.; Perera, C.; Hemar, Y. Antitumor activity of mushroom polysaccharides: a review. Food Funct 2012, 3, 1118-1130, https://doi.org/10.1039/c2fo10279j.

86. Zhang, M.; Cui, S.W.; Cheung, P.C.K.; Wang, Q. Antitumor polysaccharides from mushrooms: a review on their isolation process, structural characteristics and antitumor activity. Trends Food Sci Technol 2007, 18, 4-19, https://doi.org/10.1016/j.tifs.2006.07.013.

87. Zhang, L.; Yang, L. Properties of Auricularia auricula-judae $\beta$-D-glucan in dilute solution. Biopolymers 1995, 36, 695-700, https://doi.org/10.1002/bip.360360603.

88. Zhang, P.; Cheung, P.C.K. Evaluation of sulfated Lentinus edodes $\alpha-(1 \rightarrow 3)$-D-glucan as a potential antitumor agent. Biosci Biotechnol Biochem 2002, 66, 1052-1056, https://doi.org/10.1271/bbb.66.1052.

89. Kiho, T.; Yoshida, I.; Nagai, K.; Ukai, S.; Hara, C. $(1 \rightarrow 3)$ - $\alpha$-d-glucan from an alkaline extract of Agrocybe cylindracea, and antitumor activity of its O-(carboxymethyl)ated derivatives. Carbohydr Res 1989, 189, 273-279, https://doi.org/10.1016/0008-6215(89)84103-5.

90. Kiho, T.; Yoshida, I.; Katsuragawa, M.; Sakushima, M.; Usui, S.; Ukai, S. Polysaccharides in Fungi. XXXIV. A Polysaccharide from the Fruiting Bodies of Amanita muscaria and the Antitumor Activity of Its Carboxymethylated Product. Biol Pharma Bull 1994, 17, 1460-1462, https://doi.org/10.1248/bpb.17.1460.

91. Brown, G.D.; Taylor, P.R.; Reid, D.M.; Willment, J.A.; Williams, D.L.; Pomares, L.M.; Wong, S.Y.C.; Gordon, S. Dectin-1 Is a Major $\beta$-Glucan Receptor on Macrophages. J Exp Med 2002, 196, 407-412, https://doi.org/10.1084/jem.20020470. 
92. Shao, B.M.; Dai, H.; Xu, W.; Lin, Z.B.; Gao, X.M. Immune receptors for polysaccharides from Ganodermalucidum. Biochem Biophys Res Com 2004, 323, 133-141, https://doi.org/10.1016/j.bbrc.2004.08.069.

93. Ariizumi, K.; Shen, GL.; Shikano, S.; Xu, S.; Ritter, R.; Kumamoto, T.; Edelbaum, D.; Moitra, A.; Bergstresser P.R.; Takashima, A. Identification of a novel, dendritic cell-associated molecule, dectin-1, by subtractive cDNA cloning. J Biol Chem 2000, 275, 20157-20167, https://doi.org/10.1074/jbc.m909512199.

94. Goodridge, H.S.; Wolf, A.J.; Underhill, D.M. $\beta$-glucan recognition by the innate immune system. Immunol Rev 2009, 230, 38-50, https://doi.org/10.1111/j.1600-065x.2009.00793.x.

95. Yadav, M.; Schorey, S.J. The $\beta$-glucan receptor dectin-1 functions together with TLR2 to mediate macrophage activation by mycobacteria. Blood 2006, 108, 3168-3175, https://doi.org/10.1182/blood-200605-024406.

96. Wagner, C.; Hänsch, G.M.; Stegmaier, S.; Denefleh, B.; Hug, F.; Schoels, M. The Complement Receptor 3, CR3 (CD11b/CD18), on T Lymphocytes: Activation-Dependent Up-Regulation and Regulatory Function. Eur J Immunol 2001, 31, 1173-1180, https://doi.org/10.1002/1521-4141(200104)31:4\%3C1173::aidimmu1173\%3E3.0.co;2-9.

97. Li, B.; Allendorf, D.J.; Hansen, R.; Marroquin, J.; Ding, C.; Cramer, D.E.; Yan, J. Yeast $\beta$-glucan amplifies phagocyte killing of iC3b-Opsonized tumor cells via complement receptor 3-Syk-phosphatidylinositol 3kinase pathway. J Immunol 2006, 177, 1661-1669, https://doi.org/10.4049/jimmunol.177.3.1661.

98. Zani, I.A.; Stephen, S.L.; Mughal, N.A.; Russel, D.; Homer-Vanniasinkam, S.; Wheatcroft, S.B.; Ponnambalam, S. Scavenger Receptor Structure and Function in Health and Disease. Cells 2015, 4, 178201, https://dx.doi.org/10.3390\%2Fcells4020178.

99. Lull, C.; Wichers, H.J; Savelkoul, H.F.J. Antiinflammatory and Immunomodulating Properties of Fungal Metabolites. Mediators Inflamm 2005, 2005, 63-80.

100.Underhill, D.M.; Ozinsky, A.; Hajjar, A.M.; Stevens, A.; Wilson, B.C.; Bassetti, M.; Aderem, A. The Tolllike receptor 2 is recruited to macrophage phagosomes and discriminates between pathogens. Nature 1999, 401, 811-815, https://doi.org/10.1038/44605.

101.Cao, Y.; Xu, X.; Liu, S.; Huang, L.; Gu, J. Ganoderma: A Cancer Immunotherapy Review Front Pharmacol 2018, 9, 1-29, https://dx.doi.org/10.3389\%2Ffphar.2018.01217.

102.Hetland, G.; Johnson, E.; Lyberg, T.; Kvalheim, G. The mushroom Agaricus blazei Murill elicits medicinal effects on tumor, infection, allergy, and inflammation through its modulation of innate immunity and amelioration of Th1/Th2 imbalance and inflammation. Adv Pharmacol Sci 2011, 2011, 1-11.

103.Chen, Q.; Qi, C.; Peng, G.; Liu, Y.; Zhang, X.; Meng, Z. Immune-enhancing effects of a polysaccharide PRG1-1 from Russula griseocarnosa on RAW264.7 macrophage cells via the MAPK and NF- $\mathrm{BB}$ signalling pathways. Food Agr Immunol 2018, 29, 833-844, https://doi.org/10.1080/09540105.2018.1461198.

104.Mocellin, S.; Rossi, C.R.; Pilati, P.; Nitti, D. Tumor necrosis factor, cancer and anti-cancer therapy. Cytokine Growth Factor Rev 2005, 16, 35-53, https://doi.org/10.1016/j.cytogfr.2004.11.001.

105.Wang, S.Y.; Hsu, M.L.; Hsu, H.C.; Tzeng, C.H.; Lee, S.S.; Shiao, M.S.; Ho, C.K. The antitumor effect of Ganoderma lucidum is mediated by cytokines released from activated macrophages and $\mathrm{T}$ lymphocytes. Int $J$ Cancer 1997, 70, 699-705, https://doi.org/10.1002/(SICI)10970215(19970317)70:6<699::AID-IJC12>3.0.CO;2-5.

106. Yokoyama, W.M.; Kim, S.; French, A.R. The dynamic life of natural killer cells. Annu Rev Immunol 2004, 22, 405-429, https://doi.org/10.1146/annurev.immunol.22.012703.104711.

107.Takimoto, H.; Wakita, D.; Kawaguchi, K.; Kumazawa, Y. Potentiation of cytotoxic activity in naive and tumor-bearing mice by oral administration of hotwater extracts from Agaricus brazei fruiting bodies. Biol Pharm Bull 2004, 27, 404-406, https://doi.org/10.1248/bpb.27.404.

108.Zhang, W.; Wang, Y.; Hou, Y. Effects of Chinese medicinal fungus water extract on tumor metastasis and some parameters of immune function. Int Immunopharmacol 2004, 4, 461-468, https://doi.org/10.1016/j.intimp.2004.01.014.

109.Kanazawa, M.; Mori, Y.; Yoshihara, K.; Iwadate, M.; Suzuki, S.; Endoh, Y.; Ohki, S.; Takita, K.; Sekikawa, K.; Takenoshita, S. Effect of PSK on the maturation of dendritic cells derived from human peripheral blood monocytes. Immunol Let 2004, 91, 229-238, https://doi.org/10.1016/j.imlet.2003.12.007.

110.Cao, L.Z.; Lin, Z.B. Regulation on maturation and function of dendritic cells by Ganoderma lucidum polysaccharides. Immunol Let 2002, 83, 163-169, https://doi.org/10.1016/s0165-2478(02)00087-1.

111.Petersone, L.; Edner, N.M.; Ovcinnikovs, V.; Heuts, F.; Ross, E.M.; Ntavli, E.; Wang, C.J.; Walker, L.S.K. T Cell/B Cell Collaboration and Autoimmunity: An Intimate Relationship. Front Immunol 2018, 9, 1-10, https://doi.org/10.3389/fimmu.2018.01941.

112.Inoue, A.; Kodama, N.; Nanba, H. Effect of Maitake (Grifola frondosa) D-fraction on the control of the T lymph node Th-1/Th-2 proportion. Biol PharmBull 2002, 25, 536-540, https://doi.org/10.1248/bpb.25.536.

113.Chihara, G.; Hamuro, J.; Maeda, Y.Y.; Shiio, T.; Suga T.; Takasuka, N.; Sasaki, T. Antitumor and metastasis-inhibitory activities of lentinan as an immunomodulator: an overview. Cancer Detect Prev Sup 1987, $1,423-443$. 
114.Suzuki, Y.; Adachi, Y.; Ohno, N.; Yadomae, T. Th1/Th2- balancing immunomodulating activity of gelforming $(1 \rightarrow 3)-\beta$-glucans from fungi. Biol Pharm Bull 2001, 24, 811-819, https://doi.org/10.1248/bpb.24.811.

115.Hsu, H.C.; Hsu, C.I.; Lin, R.H.; Kao, C.L.; Lin, J.Y. Fip-vvo, a new fungal immunomodulatory protein isolated from Volvariella volvacea. Biochem $J \quad 1997, \quad 323, \quad 557-565$, https://dx.doi.org/10.1042\%2Fbj3230557.

116.Bao, X.F.; Wang, X.S.; Dong, Q.; Fang, J.N.; Li, X.-Y. Structural features of immunologically active polysaccharides from Ganoderma lucidum. Phytochem 2002, 59, 175-181, https://doi.org/10.1016/s00319422(01)00450-2.

117.Kim, G.Y.; Park, S.K.; Lee, M.K; Lee, S.H.; Oh, Y.H.; Kwak, J.Y.; Yoon, S.; Lee, J.D.; Park, Y.M. Proteoglycan isolated from Phellinus linteus activates murine B lymphocytes via protein kinase $\mathrm{C}$ and protein tyrosine kinase. Int Immunopharmacol 2003, 3, 1281-1292, https://doi.org/10.1016/s15675769(03)00115-2.

118.Wang, G.; Wang, L.; Zhou, J.; Xu, X. The Possible Role of PD-1 Protein in Ganoderma lucidum-Mediated Immunomodulation and Cancer Treatment. Integr Cancer Ther 2019, 18, 1-13, https://doi.org/10.1177/1534735419880275.

119.Zhang, W.; Cheng, N.; Wang, Y.; Zheng, X.; Zhao, Y.; Wang, H.; ... Xia, X.Adjuvant activity of PCP-II, a polysaccharide from Poria cocos, on a whole killed rabies vaccine. Virus Res 2019, https://doi.org/10.1016/j.virusres.2019.06.001. 